\title{
Partial Oxidation of Ethane to Acetic Acid Catalyzed by MoVNbPd Catalyst Supported on Titania
}

\author{
Yousef S. Al-Zeghayer
}

\begin{abstract}
The partial oxidation of ethane to ethylene and acetic acid was examined over catalyst based on unsupported and supported Mo-V-Nb oxides with and without Pd. The supports are different types of titania. Catalyst characterization was carried out uxing XRD, SEM, and BET surface area. The reaction was carried out in differential reactor at temperature range $200-275^{\circ} \mathrm{C}$ and total pressure 200 psi. Unsupported $\mathrm{Mo}_{16} \mathrm{~V}_{6.37} \mathrm{Nb}_{2.05} \mathrm{O}_{\mathrm{x}}$ showed activity and selectivities resemble those reported previously. Titania with different grades was examined as a support for $\mathrm{Mo}_{16} \mathrm{~V}_{6.37} \mathrm{Nb}_{2.05} \mathrm{O}_{\mathrm{x}}$. The selectivities of products kept without significant change when titania $P 25$ was used as a support for $\mathrm{Mo}_{16} \mathrm{~V}_{6.37} \mathrm{Nb}_{2.05} \mathrm{O}_{\mathrm{x}}$ whereas the other grades cristal AF4.60, AF7.70, and AF12.5 showed either low catalytic activities and/or combustion reactions. Supported $\mathrm{Mo}_{16} \mathrm{~V}_{6.37} \mathrm{Nb}_{2.05} \mathrm{O}_{\mathrm{x}}$ over $\mathrm{TiO}_{2}(\mathrm{P25})$ led to increase the catalyst surface area from 30 to $38.58 \mathrm{~m}^{2} \mathrm{~g}^{-1}$. The introduction of trace amounts of $\mathrm{Pd}$ led to the depletion of ethylene and to a significant increase in acetic acid synthesis rate.
\end{abstract}

Index Terms-Acetic acid, ethane, ethylene, MoVNbPd catalyst, partial oxidation.

\section{INTRODUCTION}

Commercially, acetic acid is mainly produced from methanol carbonylation, which gives rise to many problems, such as corrosion and waste disposal. Methanol carbonylation accounts for $65 \%$ of the world capacity.

Considerable efforts have been made to develop alternative approaches for acetic acid production, among which the direct oxidation of ethane and ethylene to acetic acid has shown promise. As an example, a process using palladium-based heteropoly acids catalysts for ethylene oxidation to acetic acid was commercialized by Showa Denko of Japan in 1997.

In 2005, SABIC of Saudi Arabia commercialized a 30,000 tons/year acetic acid plant based on a proprietary catalytic oxidation process. The catalyst is a calcined mixture of oxides of $\mathrm{Mo}, \mathrm{V}, \mathrm{Nb}$ and $\mathrm{Pd}$, allows selectivities to acetic acid as high as $80 \%$. Combining this technology with low cost ethane may result in production economics competitive with methanol carbonylation technology.

The main reaction equations describing the oxidation of ethane are

$$
\mathrm{C}_{2} \mathrm{H}_{6}+1 / 2 \mathrm{O}_{2} \rightarrow \mathrm{C}_{2} \mathrm{H}_{4}+\mathrm{H}_{2} \mathrm{O} \quad \Delta \mathrm{H} 600{ }^{0} \mathrm{~K}=-24.59
$$

$\mathrm{kcal} / \mathrm{mole}_{2} \mathrm{H}_{4}$

$$
\mathrm{C}_{2} \mathrm{H}_{6}+3 / 2 \mathrm{O}_{2} \rightarrow \mathrm{CH}_{3} \mathrm{COOH}+\mathrm{H}_{2} \mathrm{O} \Delta \mathrm{H} \quad 600{ }^{0} \mathrm{~K}=
$$

Manuscript received August 13, 2013; revised November 5, 2013.

Y. S. Al-Zeghayer is with Department of Chemical Engineering and is a Director of Industrial Catalysts Chair, King Saud University (Riyadh, Saudi Arabia) (e-mail: yszs@ksu.edu.sa).
- $116.54 \mathrm{kcal} / \mathrm{mole} \mathrm{CH}_{3} \mathrm{COOH}$

$$
\mathrm{C}_{2} \mathrm{H}_{6}+5 / 2 \mathrm{O}_{2} \rightarrow 2 \mathrm{CO}+3 \mathrm{H}_{2} \mathrm{O} \quad \Delta \mathrm{H} 600{ }^{0} \mathrm{~K}=-90.13
$$

$\mathrm{kcal} / \mathrm{mole} \mathrm{CO}$

$$
\mathrm{C}_{2} \mathrm{H}_{6}+7 / 2 \mathrm{O}_{2} \rightarrow 2 \mathrm{CO}_{2}+3 \mathrm{H}_{2} \mathrm{O} \quad \Delta \mathrm{H} 600{ }^{0} \mathrm{~K}=-157.92
$$

$\mathrm{Kcal} /$ mole $\mathrm{CO}_{2}$

Thus all the reactions are highly exothermic and mainly irreversible.

The study of MoVNb catalyst for the partial oxidation of ethane to ethylene and acetic acid was pioneered by the work of Thorsteinson et al. [1] and Young and Thorsteinson [2] .The use of high pressure and the addition of steam to the feed improve the selectivity to acetic acid. The process requires a pressure of about 20 atm and acetic acid selectivity is about $20 \%$, while ethylene selectivity is about $70 \%$.

Three patents by Karim et al.[3]-[5] have been granted to SABIC as a result of work carried out at King Saud University. In these patents, it is shown that the addition of $\mathrm{Pd}$ to the MoVNb catalyst greatly increases the selectivity to acetic acid to about $80 \%$ and completely oxidizes $\mathrm{CO}$ to $\mathrm{CO}_{2}$. The same idea was also discovered by Borchert and Dingerdissen [6]. The mechanism and the kinetics of the reaction were presented by Linke et al. [7], [8].

$\mathrm{Li}$ and Iglesia [9], [10] found that precipitation of Mo, $\mathrm{V}$, and $\mathrm{Nb}$ salts solution in the presence of colloidal $\mathrm{TiO}_{2}$ (titania P25 from Degussa) led to a 10-fold increase in ethylene and acetic acid rates (per active oxide) without significant changes in selectivity relative to unsupported samples. The introduction of trace amounts of $\mathrm{Pd}$ $(0.0025-0.01$ wt.\%), as a physical mixture of separate 0.3 wt. $\% \mathrm{Pd} / \mathrm{Si} \mathrm{O}_{2}$, led to the near complete depletion of ethylene and to a significant increase in acetic acid synthesis rate.

In this paper, we examine the partial oxidation of ethane to ethylene and acetic acid over catalyst based on unsupported and titania supported Mo-V-Nb oxides with and without the addition of Pd. Different grades of titania are used.

\section{EXPERIMENTAL}

\section{A. Catalyst Preparation}

Mo-V-Nb oxides catalyst was prepared using a slurry method. Three aqueous solutions were prepared (a) $0.57 \mathrm{~g}$ ammonium m-vanadate dissolved in $25 \mathrm{ml}$ of water while stirring and heating at $87^{\circ} \mathrm{C}$. A yellow color solution resulted. (b) $2.16 \mathrm{~g}$ ammonium p-molybdate in $20 \mathrm{ml}$ of water while stirring and heating at $60^{\circ} \mathrm{C}$. A colorless solution resulted, (c) $0.97 \mathrm{~g}$ niobium oxalate $\left(21.5 \% \mathrm{Nb}_{2} \mathrm{O}_{5}\right)$ in $20 \mathrm{ml}$ of water while stirring and heating at $63^{\circ} \mathrm{C}$. A white colour solution was formed. $1.5 \mathrm{~g}$ oxalic acid powder was added gradually to 
vanadate solution and stirred again at $87^{\circ} \mathrm{C}$. Foam resulted while adding oxalic acid and it breaks fast. The solution color changed from yellow to dark blue. The molybdate solution was then mixed with the previous solution and stirred again for $10 \mathrm{~min}$ at $87^{\circ} \mathrm{C}$ before adding -drop-wise the niobium solution. The mixture was stirred for additional $10 \mathrm{~min}$ at $87^{\circ} \mathrm{C}$. The water was then evaporated. In case of supported catalyst, $5.0 \mathrm{gm}$ of support (titania with different grades) is added to the Mo-solution while stirring and heating at $85^{\circ} \mathrm{C}$ until the liquid evaporated. For catalysts containing palladium, $10 \% \mathrm{Pd}$ on charcoal in oxidized form is added in the appropriate amount.

The resulting paste was aged for 24 hours, then dried for $16 \mathrm{~h}$ at $120^{\circ} \mathrm{C}$ and calcinated for $0.5 \mathrm{~h}$ at $350^{\circ} \mathrm{C}$. The bulk standard catalyst is donated herein as $(\mathrm{M}) ; \mathrm{Mo}_{16} \mathrm{~V}_{6.37} \mathrm{Nb}_{2.05}$.

The catalyst weight for a supported catalyst is between $7.10-7.20 \mathrm{gm}$.

\section{B. Catalyst Characterization}

Crystalline phase of $\mathrm{TiO}_{2}$ and $\mathrm{TiO}_{2}$-supported catalysts were analyzed by Powder X-ray diffraction (XRD, Ultima IV) with $\mathrm{Cu}$ radiation $(40 \mathrm{kV}, 40 \mathrm{~mA})$. The $\mathrm{XRD}$ patterns were collected at a scan rate of 2.0 degree/min in the range $2 \Theta=$ 5-70 degrees. SEM images were taken on NOVA NANO LAB microscope.BET surface area of the catalysts were determined by $\mathrm{N}_{2}$ adsorption at liquid nitrogen temperature using a Micromeritics ASAP 2020 automated system and the Brunauer-Emmet-Teller (BET) method using nitrogen adsorption- desorption at $77 \mathrm{~K}$.

The scanning electron microscopy (SEM) results for Pd on activated charcoal (Fig .1) show that $\mathrm{Pd} \mathrm{O}$ is in a nano form.

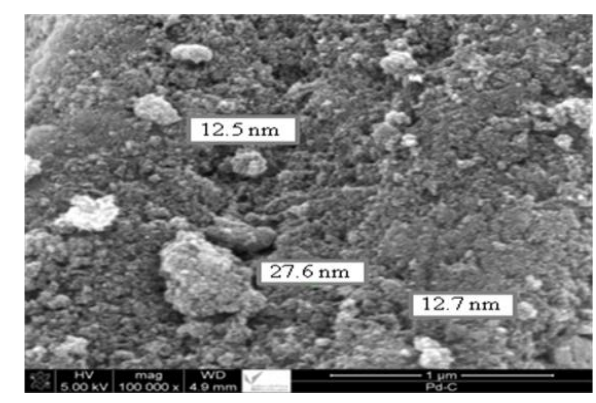

Fig. 1. SEM for Pd on charcoal.

\section{Catalytic Tests Set up}

Catalytic activity and selectivity tests were carried out in an apparatus comprised of a reaction section and analysis section.

\section{1) Reaction section}

Reaction section mainly consists of (Fig. 2)

- Oven is a convection zone that surrounds the reactor and where the sample valves are fixed. It is a stainless steel box with $40 \times 40 \times 40 \mathrm{~cm}$ dimensions. The oven was designed with maximum temperature around $350^{\circ} \mathrm{C}$ and its temperature is controlled by Omega temperature controller.

- Reactor which is Micro-reactor overall length is 150 $\mathrm{mm}$ with inside diameter of made of $6.35 \mathrm{~mm}$ stainless steel and surrounded by brass block. The block is surrounded by mica band heater. Reactor temperature can be measured by a thermocouple touched reactor wall. The reactor is fixed inside the oven where the temperature is stable. The authors of the accepted manuscripts will be given a copyright form and the form should accompany your final submission.

The reaction products which exit from reactor are analyzed in gas chromatography.

\section{2) Analysis section}

The Gas Chromatography that is shown in Fig. 2 is a Shamudzu equipment of model AS2010. Thermal conductivity detector (TCD) is used for the analysis. It was conFigd to analyze reaction products as well as feed mixture using Propack Q and carboxeen 1000 as columns.

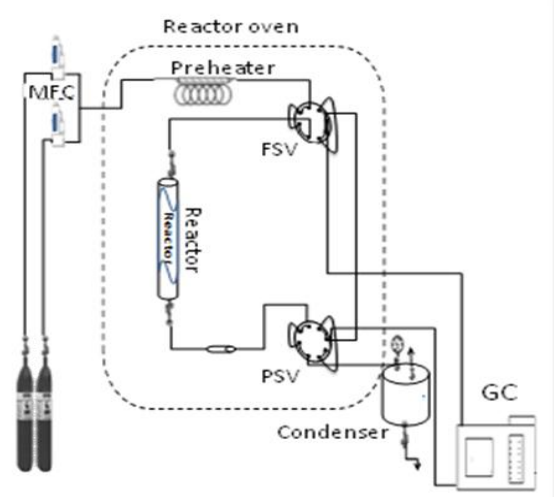

Fig. 2. Schematic of experimental setup, reactants mass flow controller (MFC's), feed sample valve (FSV), products sample valve (PSV).

\section{RESUlTS AND DISCUSSION}

\section{A. Ethane Oxidation to Ethylene and Acetic Acid on Bulk} $\mathrm{Mo}_{16} \mathrm{~V}_{6.37} \mathrm{Nb}_{2.05} \mathrm{O}_{x}$ Catalyst

$\mathrm{Mo}_{16} \mathrm{~V}_{6.37} \mathrm{Nb}_{2.05} \mathrm{O}_{\mathrm{x}}$ catalyst is considered as a high active and selective catalyst as well as its superior long-term stability compared to other systems for ethane oxidation. Oxidations rates and products selectivities on bulk $\mathrm{Mo}_{16} \mathrm{~V}_{6.37} \mathrm{Nb}_{2.05} \mathrm{O}_{\mathrm{x}}(\mathrm{M})$ catalyst were measured at temperature range $225-275{ }^{\circ} \mathrm{C}$ and $200 \mathrm{psi}$ total pressure. The reactants flow rate was maintained at $15 \mathrm{ml} / \mathrm{min}$. Bulk $\mathrm{Mo}_{16} \mathrm{~V}_{6.37} \mathrm{Nb}_{2.05} \mathrm{O}_{\mathrm{x}}$ catalyst gave $23-35 \%$ acetic acid selectivity and $62-76 \%$ ethylene selectivity at ethane conversion $6-17 \%$ (Fig. 3) these selectivities resemble those reported in previous works.

It is seen that acetic acid selectivities increased slightly with ethane conversion (from $23 \%$ to $35 \%$ ), while ethylene selectivities concurrently decreased (from $76 \%$ to $62 \%$ ), consistent with the involvement of ethylene as a reactive intermediate in acetic acid synthesis. The non zero acetic acid selectivity, evident by extrapolation to zero ethane conversion (Fig. 3 \& Table I) suggests, however that a substantial fraction of the acetic acid forms via direct oxidation of ethane.

\section{B. Support Effects on Ethane Oxidation Catalyzed by Supported $\mathrm{Mo}_{16} \mathrm{~V}_{6.37} \mathrm{Nb}_{2.05} \mathrm{O}_{x}$}

Titania with different grades has been used as supports in the study of support effect on $\mathrm{Mo}_{16} \mathrm{~V}_{6.37} \mathrm{Nb}_{2.05} \mathrm{O}_{\mathrm{x}}$ activities. Standard catalyst $\mathrm{Mo}_{16} \mathrm{~V}_{6.37} \mathrm{Nb}_{2.05} \mathrm{O}_{\mathrm{x}}$ was supported over four different grades of Titania. In Table II, the BET surface areas of the different supports as well as the bulk and supported catalyst are given. 
TABLE I: SUMMARY OF EXPERIMENTAL RUNS OF BULK $\mathrm{Mo}_{16} \mathrm{~V}_{6.37} \mathrm{Nb}_{2.05} \mathrm{O}_{\mathbf{x}}(\mathrm{M})$ CATALYST (REACTION PRESSURE: 200 PSI FOR, F/W: 50 ML/MIN.G. CAT.)

\begin{tabular}{|c|c|c|c|c|c|c|c|c|c|}
\hline Cat. & $\mathrm{T}\left({ }^{\circ} \mathrm{C}\right)$ & \multirow{2}{*}{$\begin{array}{l}\text { Oxygen } \\
\text { Con. }(\%)\end{array}$} & \multirow{2}{*}{$\begin{array}{c}\text { Ethane } \\
\text { Con. }(\%)\end{array}$} & \multicolumn{2}{|c|}{ Selectivity ( \%) } & \multicolumn{2}{|c|}{ Yield $* 10^{-2}(\%)$} & \multicolumn{2}{|c|}{ Space time yield $(\mathrm{gm} / \mathrm{kgh})$} \\
\hline Name & & & & Ethylene & Acetic Acid & Ethylene & Acetic Acid & Ethylene & Acetic Acid \\
\hline M & 225 & 27.31 & 5.5 & 75.71 & 22.82 & 4.16 & 1.26 & 127.9 & 83.2 \\
\hline M & 250 & 61.99 & 12.35 & 67.78 & 29.74 & 8.37 & 3.67 & 257.4 & 241.8 \\
\hline M & 275 & 88.76 & 16.93 & 61.42 & 35.04 & 10.4 & 5.93 & 319.8 & 390.7 \\
\hline
\end{tabular}

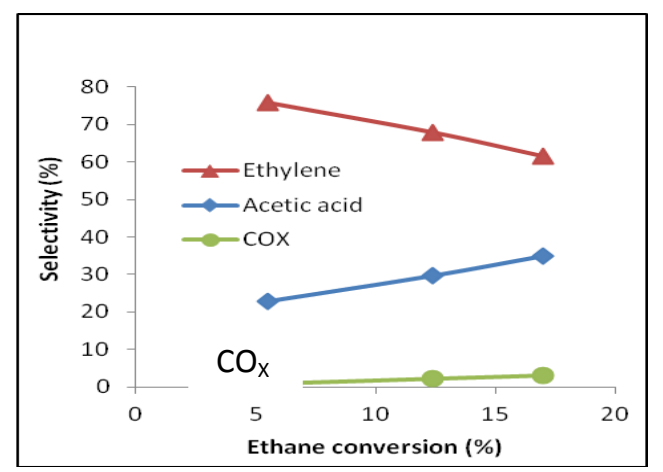

Fig. 3. Product selectivities as a function of ethane conversion for ethane oxidation on $\mathrm{Mo}_{16} \mathrm{~V}_{6.37} \mathrm{Nb}_{2.05} \mathrm{O}_{\mathrm{x}}$ catalyst $(\mathrm{T}=225-275 \mathrm{C}, \mathrm{P}=200$ psi, F/W: 50 $\mathrm{ml} / \mathrm{min} . \mathrm{g}$. Cat.)

TABLE II: BET SURFACE AREAS OF THE DIFFERENT SUPPORTS

\begin{tabular}{|c|c|}
\hline Cristal & Cristal BET surface area $\left(\mathbf{m}^{2} / \mathbf{g}\right)$ \\
\hline $\mathrm{AF}(4.60)$ & 26.96 \\
\hline $\mathrm{AF}(7.70)$ & 33.8 \\
\hline $\mathrm{AF}(12.5)$ & 2.5 \\
\hline Degussa P25 & 54.0 \\
\hline
\end{tabular}

The surface area of the standard catalyst is $30 \mathrm{~m} 2 / \mathrm{g}$

The surface area of the standard catalyst supported on P25 is $38.58 \mathrm{~m} 2 / \mathrm{g}$.

Cristal titania have mainly anatase structure. Degussa P25 contains about $81 \%$ anatase and $19 \%$ rutile phase.

The prepared catalysts are:
1) $\mathrm{Mo}_{16} \mathrm{~V}_{6.37} \mathrm{Nb}_{2.05} \mathrm{O}_{\mathrm{x}} / \mathrm{AF}(4.6) \quad \mathrm{S}_{4.60} \mathrm{M}$
2) $\mathrm{Mo}_{16} \mathrm{~V}_{6.37} \mathrm{Nb}_{2.05} \mathrm{O}_{\mathrm{x}} / \mathrm{AF}(7.7) \quad \mathrm{S}_{7.70} \mathrm{M}$
3) $\mathrm{Mo}_{16} \mathrm{~V}_{6.37} \mathrm{Nb}_{2.05} \mathrm{O}_{\mathrm{x}} / \mathrm{AF}(12.5) \quad \mathrm{S}_{12.5} \mathrm{M}$
4) $\mathrm{Mo}_{16} \mathrm{~V}_{6.37} \mathrm{Nb}_{2.05} \mathrm{O}_{\mathrm{x}} / \mathrm{P} 25 \quad \mathrm{~S}_{25} \mathrm{M}$

The catalytic activity of the prepared catalysts was evaluated at temperature range $200-275 \mathrm{C}$ and feed flow rate $15 \mathrm{ml} / \mathrm{min}$. Total pressure was maintained at 200 psi. The results of catalysts testing are presented in Table III and Figs (4-6).

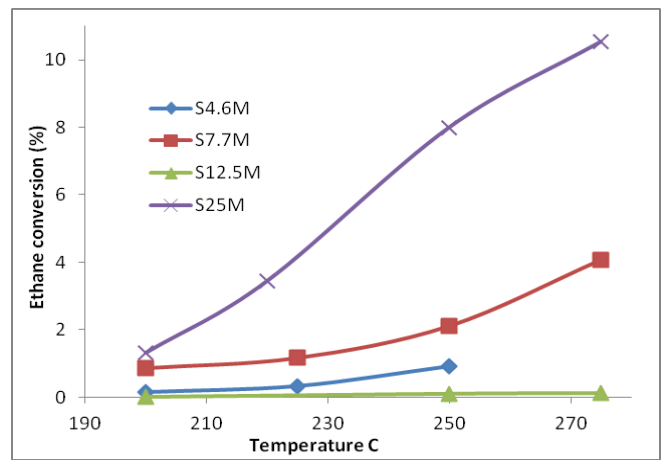

Fig. 4. Ethane conversion as a function on reaction temperature for ethane oxidation over different supported $\mathrm{Mo}_{16} \mathrm{~V}_{6.37} \mathrm{Nb}_{2.05} \mathrm{O}_{\mathrm{x}}$ catalysts $(\mathrm{P}=200 \mathrm{psi}$, F/W: $15 \mathrm{ml} / \mathrm{min} . \mathrm{g}$. Cat.)

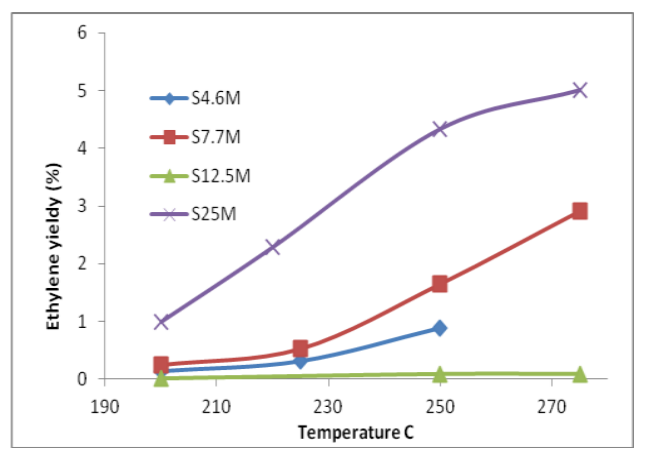

Fig. 5. Ethylene yield as a function on reaction temperature for catalytic ethane oxidation over different supported $\mathrm{Mo}_{16} \mathrm{~V}_{6.37} \mathrm{Nb}_{2.05} \mathrm{O}_{\mathrm{x}}$ catalysts (P=200 psi, F/W: 15 ml/min.g.Cat.)

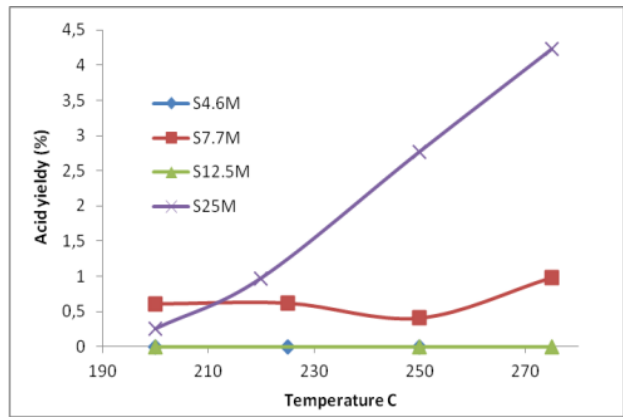

Fig. 6. Acetic acid yield as a function on reaction temperature for catalytic ethane oxidation over different supported $\mathrm{Mo}_{16} \mathrm{~V}_{6.37} \mathrm{Nb}_{2.05} \mathrm{O}_{\mathrm{x}}$ catalysts ( $\mathrm{P}=200$ psi, F/W: $15 \mathrm{ml} / \mathrm{min} . \mathrm{g}$. Cat.)

From the results, it is clear that the catalytic activity practically $\mathrm{S} 25 \mathrm{M}$ is sensitive to reaction temperature. In case of $\mathrm{S}_{25} \mathrm{M}$, ethane conversion was increased from $1.31 \%$ at $200 \mathrm{C}$ to $10.53 \%$ at $275^{\circ} \mathrm{C}$ where oxygen conversion was increased from $7.74 \%$ to $81.39 \%$ at the same temperature range. On the other hand $\mathrm{S}_{7.70} \mathrm{M}$ catalyst showed lower activity than $\mathrm{S}_{25} \mathrm{M}$ and the highest ethane and oxygen conversions were $4.06 \%$ and $19.37 \%$ respectively.

$\mathrm{S}_{4.6} \mathrm{M}$ and $\mathrm{S}_{12.5} \mathrm{M}$ catalysts have shown too lower or almost no activities if they are compared with $\mathrm{S}_{25} \mathrm{M}$ and $\mathrm{S}_{7.7} \mathrm{M}$.

Good performance of P25 and cristal 7.7 should be correlated to their relatively large surface area.

The activities of these catalysts significantly reflected on products selectivities where the same order of the catalytic activity was repeated when we talk about catalytic productivities. Again, $\mathrm{S}_{25} \mathrm{M}$ occupied the first one in products yields where ethylene and acetic acid yield reordered $5 \%$ and $4.23 \%$ respectively to become the heights values obtained.

As a result, these supported catalysts can be arranged based on their activities and products yield to become $S_{25} \mathrm{M}$ is the best which has shown the highest activity and products yield. $\mathrm{S}_{7.7} \mathrm{M}$ came the second with lower activity than $\mathrm{S}_{25} \mathrm{M}$. $\mathrm{S}_{4.6} \mathrm{M}$ and $\mathrm{S}_{12.5} \mathrm{M}$ have shown almost no activity for $\mathrm{S}_{12.5} \mathrm{M}$ or too low activity for $\mathrm{S}_{4.6} \mathrm{M}$. 
TABLE III: SUMMARY OF EXPERIMENTAL RUNS OF SUPPORTED $\mathrm{Mo}_{16} \mathrm{~V}_{6.37} \mathrm{Nb}_{2.05} \mathrm{O}_{\mathrm{x}}(\mathrm{MI})$ CATALYSTS (REACTION PRESSURE: 200 PSI FOR, F/W: 15 ML/MIN.G. CAT.)

\begin{tabular}{|c|c|c|c|c|c|c|c|c|c|}
\hline \multirow{2}{*}{$\begin{array}{c}\text { Cat. } \\
\text { Name }\end{array}$} & \multirow[t]{2}{*}{$\mathrm{T}(\mathrm{C})$} & \multirow{2}{*}{$\begin{array}{c}\text { Oxygen } \\
\text { Con. (\%) }\end{array}$} & \multirow{2}{*}{$\begin{array}{c}\text { Ethane } \\
\text { Con. (\%) }\end{array}$} & \multicolumn{2}{|c|}{ Selectivity ( \% ) } & \multicolumn{2}{|c|}{ Yield $* 10^{-2}$} & \multicolumn{2}{|c|}{ Space time yield(gm/kgh) } \\
\hline & & & & Ethylene & Acetic Acid & Ethylene & Acetic Acid & Ethylene & Acetic Acid \\
\hline $\mathrm{S} 4.6 \mathrm{M}$ & 200 & 0.4 & 0.15 & 100 & 0 & 0.15 & 0 & 4.6 & 0 \\
\hline $\mathrm{S} 4.6 \mathrm{M}$ & 225 & 1.09 & 0.33 & 97.24 & 0 & 0.32 & 0 & 9.8 & 0 \\
\hline $\mathrm{S} 4.6 \mathrm{M}$ & 250 & 4.85 & 0.91 & 96.68 & 0 & 0.88 & 0 & 27.1 & 0 \\
\hline $\mathrm{S} 7.7 \mathrm{M}$ & 200 & 0.86 & 0.87 & 29.01 & 70.26 & 0.25 & 0.61 & 7.7 & 40.2 \\
\hline $\mathrm{S} 7.7 \mathrm{M}$ & 225 & 2.36 & 1.17 & 45.44 & 53.25 & 0.53 & 0.62 & 16.3 & 40.9 \\
\hline $\mathrm{S} 7.7 \mathrm{M}$ & 250 & 8.55 & 2.11 & 78.03 & 19.21 & 1.65 & 0.41 & 50.7 & 27 \\
\hline $\mathrm{S} 7.7 \mathrm{M}$ & 275 & 19.37 & 4.06 & 71.75 & 24.2 & 2.91 & 0.98 & 89.5 & 64.6 \\
\hline $\mathrm{S} 12.5 \mathrm{M}$ & 200 & 1.09 & 0.02 & 60.75 & 0 & 0.01 & 0 & 0.3 & 0 \\
\hline $\mathrm{S} 12.5 \mathrm{M}$ & 250 & 1.9 & 0.11 & 83.05 & 0 & 0.09 & 0 & 2.7 & 0 \\
\hline $\mathrm{S} 12.5 \mathrm{M}$ & 275 & 1.95 & 0.13 & 71.6 & 0 & 0.09 & 0 & 2.7 & 0 \\
\hline $\mathrm{S} 25 \mathrm{M}$ & 200 & 7.74 & 1.31 & 76.7 & 19.14 & 1 & 0.25 & 30.7 & 16.5 \\
\hline $\mathrm{S} 25 \mathrm{M}$ & 220 & 20.16 & 3.44 & 66.53 & 28.13 & 2.29 & 0.97 & 70.4 & 63.9 \\
\hline $\mathrm{S} 25 \mathrm{M}$ & 250 & 59.01 & 7.99 & 54.23 & 34.71 & 4.33 & 2.77 & 133.1 & 182.5 \\
\hline $\mathrm{S} 25 \mathrm{M}$ & 275 & 81.39 & 10.53 & 48 & 40 & 5 & 4.23 & & \\
\hline
\end{tabular}

This comparison leads us clearly to choose $\mathrm{TiO}_{2} \mathrm{P} 25$ as a support of $\mathrm{Mo}_{16} \mathrm{~V}_{6.37} \mathrm{Nb}_{2.05} \mathrm{O}_{\mathrm{x}}$ catalyst for partial oxidation of ethane in this study. This choice is compatible with the findings of the previous works. Li \& Iglesia [9] concluded that $\mathrm{TiO}_{2} \mathrm{P} 25$ favor the formation of active structures without forming unselective linkages between active oxides and support surfaces or other unselective or inactive structures.

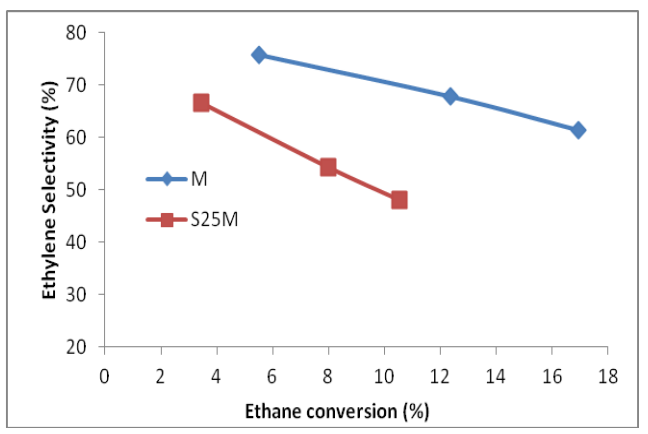

Fig. 7. Ethylene selectivity as a function of ethane conversion for Ethane oxidation on $\mathrm{Mo}_{16} \mathrm{~V}_{6.37} \mathrm{Nb}_{2.05} \mathrm{O}_{\mathrm{x}}$ and $\mathrm{Mo}_{16} \mathrm{~V}_{6.37} \mathrm{Nb}_{2.05} \mathrm{O}_{\mathrm{x}} / \mathrm{TiO}_{2}$ catalysts ( $\mathrm{T}=200-275 \mathrm{C}: \mathrm{P}=200$ psi, F/W: $15 \mathrm{ml} / \mathrm{min}$. g.cat)

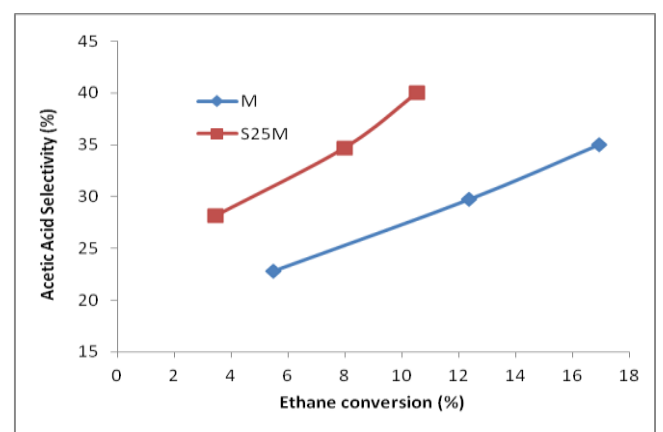

Fig. 8. Acetic acid selectivity as a function of ethane conversion for Ethane oxidation on $\mathrm{Mo}_{16} \mathrm{~V}_{6.37} \mathrm{Nb}_{2.05} \mathrm{O}_{\mathrm{x}}$ and $\mathrm{Mo}_{16} \mathrm{~V}_{6.37} \mathrm{Nb}_{2.05} \mathrm{O}_{\mathrm{x}} / \mathrm{TiO} 2$ catalysts ( $\mathrm{T}=200-2750 \mathrm{C}: \mathrm{P}=200 \mathrm{psi}, \mathrm{F} / \mathrm{W}: 15 \mathrm{ml} / \mathrm{min} . \mathrm{g}$. Cat.)

Fig. 7 and Fig. 8 show ethane oxidation on supported $\mathrm{Mo}_{16} \mathrm{~V}_{6.37} \mathrm{Nb}_{2.05} \mathrm{O}_{\mathrm{x}} \quad / \quad \mathrm{TiO} \quad \mathrm{Mo}_{16} \mathrm{~V}_{6.37} \mathrm{Nb}_{2.05} \mathrm{O}_{\mathrm{x}}$ powders (23-35\%).Ethylene selectivities concurrently decreased to (66-48\%) as a result of its subsequent conversion to acetic acid and $\mathrm{CO}_{\mathrm{x}}$. Thus, the structures formed during preparation in the presence of $\mathrm{TiO}_{2}$ appear to have a higher surface area $\left(38.58 \mathrm{~m}^{2} \mathrm{~g}^{-1}\right)$ exposed to ethane reactants. These conclusions corresponds largely with the findings of Li \& Iglesia [9] who found that the synthesis rate of acetic acid was enhanced by structural dispersion of active oxides on $\mathrm{TiO}_{2}$ more than ten times higher synthesis rate was achieved with similar selectivities to all the products.

\section{Ethane Oxidations in the Presence Nano-Palladium as Co-Catalysts}

Ethane oxidation on $\mathrm{Mo}_{16} \mathrm{~V}_{6.37} \mathrm{Nb}_{2.05} \mathrm{O}_{\mathrm{x}}$ and $\mathrm{Mo}_{16} \mathrm{~V}_{6.37} \mathrm{Nb}_{2.05} \mathrm{O}_{\mathrm{x}} / \mathrm{TiO}_{2}$ gave in the best condition around $40 \%$ acetic acid selectivity and more than $48 \%$ ethylene selectivity. Thus, it appears that higher acetic acid selectivities require the incorporation of catalytic functions for ethylene oxidation to acetic acid. The source of palladium is $10 \%$ palladium on activated charcoal in an oxidized form. The present study focus on the discussion of ethane oxidation when palladium in nano forms are involved. In this section we will look for the optimum content of both Pd that can be added to get the highest selectivity of acetic acid.

\section{1) Effect of palladium content}

The same supports in previous study were also used to explore the effect of palladium contents. Mo-V-Nb standard catalyst containing fixed amount of nano-palladium, was prepared and supported on the different grades of titanium dioxide, four catalysts were prepared as list below:
1) $\mathrm{Mo}_{16} \mathrm{~V}_{6.37} \mathrm{Nb}_{2.05} \mathrm{Pd}_{1.844} \mathrm{O}_{\mathrm{x}} / \mathrm{AF} 4.60$
$\mathrm{S}_{4.60} \mathrm{M}$ PC21
2) $\mathrm{Mo}_{16} \mathrm{~V}_{6.37} \mathrm{Nb}_{2.05} \mathrm{Pd}_{1.844} \mathrm{O}_{\mathrm{x}} / \mathrm{AF} 7.70$
$\mathrm{S}_{7.70} \mathrm{M} \mathrm{PC} 21$
3) $\mathrm{Mo}_{16} \mathrm{~V}_{6.37} \mathrm{Nb}_{2.05} \mathrm{Pd}_{1.844} \mathrm{O}_{\mathrm{x}} / \mathrm{AF} 12.50$
$\mathrm{S}_{12.5} \mathrm{M}$ PC21
4) $\mathrm{Mo}_{16} \mathrm{~V}_{6.37} \mathrm{Nb}_{2.05} \mathrm{Pd}_{1.844} \mathrm{O}_{\mathrm{x}} / \mathrm{P} 25$
$\mathrm{S}_{25} \mathrm{MPC} 21$

Palladium loading for these catalysts was $2.1 \%$. The reaction conditions were mentioned as before where the temperature range was $200-275^{\circ} \mathrm{C}$ and the feed flow rate and total pressure were $15 \mathrm{ml} / \mathrm{min}$ and 200 psi respectively. The reactions results are Table IV and represented in Figs. 9-11. 
TABLE IV: SUMMARY OF EXPERIMENTAL RUNS OF SUPPORTED $\mathrm{Mo}_{16} \mathrm{~V}_{6.37} \mathrm{Nb}_{2.05} \mathrm{Pd}_{0.196} \mathrm{O}_{\mathrm{x}}(\mathrm{SIMPC} 21$ ) CATALYSTS (REACTION PRESSURE: 200 PSI FOR, F/W: 15 ML/MIN.G. CAT.)

\begin{tabular}{|c|c|c|c|c|c|c|c|c|c|}
\hline Cat. & $\mathrm{T}(\mathrm{C})$ & Oxygen & Ethane & \multicolumn{2}{|c|}{ Selectivity $(\%)$} & \multicolumn{2}{|c|}{ Yield $* 10^{-2}$} & \multicolumn{2}{c|}{ Space time yield(gm/kgh) } \\
\hline Name & & Con. $(\%)$ & Con. $(\%)$ & Ethylene & Acetic Acid & Ethylene & Acetic Acid & Ethylene & Acetic Acid \\
\hline S4.6MPC21 & 200 & 0.39 & 0.17 & 92.54 & 0 & 0.16 & 0 & 4.9 & 0 \\
\hline S4.6MPC21 & 225 & 3.57 & 0.57 & 74.46 & 17.24 & 0.42 & 0.1 & 12.9 & 6.6 \\
\hline S4.6MPC21 & 250 & 5.84 & 1.3 & 56.01 & 33.5 & 0.73 & 0.44 & 22.4 & 29 \\
\hline S7.7MPC21 & 200 & 2.45 & 0.12 & 73.71 & 0 & 0.09 & 0 & 2.8 & 0 \\
\hline S7.7MPC21 & 225 & 5.13 & 0.4 & 45.39 & 36.15 & 0.18 & 0.15 & 5.5 & 9.9 \\
\hline S7.7MPC21 & 250 & 13.53 & 1.28 & 25.19 & 55.9 & 0.32 & 0.72 & 9.8 & 47.4 \\
\hline S7.7MPC21 & 275 & 45.66 & 3.31 & 9.86 & 57.3 & 0.33 & 1.9 & 10.1 & 125.2 \\
\hline S12.5MPC21 & 200 & 9.21 & 0.52 & 0 & 52.76 & 0 & 0.27 & 0 & 17.8 \\
\hline SM12.5PC21 & 225 & 69.47 & 3.37 & 7.47 & 29.69 & 0.25 & 1 & 7.7 & 65.9 \\
\hline SM12.5PC21 & 240 & 99.06 & 5.37 & 12.21 & 23.75 & 0.66 & 1.28 & 20.3 & 84.3 \\
\hline S25MPC21 & 200 & 15.56 & 1.37 & 0 & 80.89 & 0 & 1.11 & 0 & 73.2 \\
\hline S25MPC21 & 220 & 46.8 & 3.72 & 0 & 73.54 & 0 & 2.74 & 0 & 180.5 \\
\hline S25MPC21 & 250 & 99.23 & 9.06 & 0 & 75.3 & 0 & 6.82 & 0 & 449.4 \\
\hline
\end{tabular}

Obviously, catalytic activity of $\mathrm{S}_{12.5} \mathrm{M} \quad \mathrm{PC} 21$ has dramatically changed by adding palladium where ethane conversion has risen from almost nothing at $240^{\circ} \mathrm{C}$ to $5.37 \%$ with full oxygen conversion. On the other hand, $\mathrm{S}_{4.60} \mathrm{M}$ PC21 has shown no change in the activity compared with the same catalyst without palladium where its activity was too low.

Such addition of palladium, also affected on the catalyst supported over AF (7.7) support. $\mathrm{S}_{7.70} \mathrm{M}$ PC21 has shown slightly dropping in ethane conversion where oxygen conversion was doubled at the same range of temperature. For instance, at $275^{\circ} \mathrm{C}$ ethane conversion decreased from $4.06 \%$ for the catalyst without palladium to $3.31 \%$ for the same catalyst but in presence palladium where oxygen conversion was increased from $19.37 \%$ to $45.66 \%$.

Supported MoVNb over P25 was also affected by presences of palladium and this leads to a significant increase in oxygen conversion. For example, at $275 \mathrm{C}$ while the change in ethane conversion was within $1 \%$, oxygen conversion changed from $59 \%$ to almost full conversion.

However, we can say tentatively that the effect of palladium on catalytic activity clearly reflected on oxygen conversion where all catalysts have shown increasing in oxygen conversion.

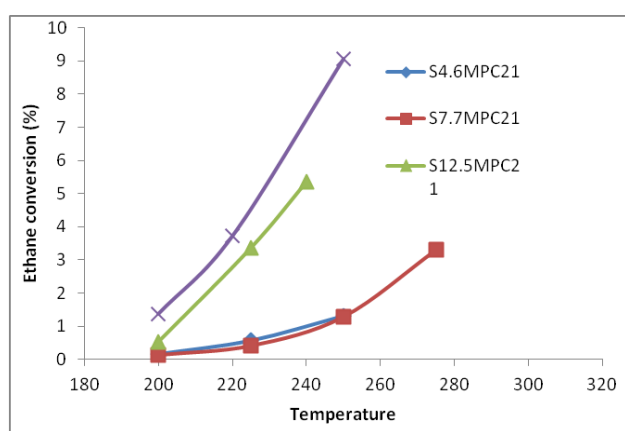

Fig. 9. Ethane conversion as a function on reaction temperature for ethane oxidation over different supported $\mathrm{Mo}_{16} \mathrm{~V}_{6.37} \mathrm{Nb}_{2.05} \mathrm{Pd}_{1.844} \mathrm{O}_{\mathrm{x}}$ catalysts ( $\mathrm{P}=200$ psi, F/W: $15 \mathrm{ml} / \mathrm{min} . \mathrm{g}$. Cat.)

It is also seen that for all catalysts increase oxygen conversion was accompanied by decreasing of ethylene selectivity and increasing selectivities of both acetic acid and carbon oxides. So we can link these variables where some oxygen was consumed in ethylene oxidation to produce acetic acid and/or Cox. This explains the high change in oxygen conversion while a slight change of ethane conversion take place.

The presence of the Pd-based co-catalyst did not influence ethane oxidation rate but markedly increased acetic acid synthesis rate by merely converting ethylene intermediates to acetic acid. Acetic acid selectivities increased from $\sim 40 \%$ to $\sim 75 \%$ while ethylene selectivities decreased from $\sim 66 \%$ to nearly depleted from the reactor effluent.

If these catalysts are compared with each other, $\mathrm{S}_{25} \mathrm{M}$ PC21 showed good activity and it recorded the best selectivity and yield for acetic acid. For instance at $2500^{\circ} \mathrm{C}$ it gave $75.3 \%$ and

$6.83 \times 10^{-2}$ acetic acid selectivity and yield respectively where the nearest values were recorded is 57.3 and $1.9 * 10^{-2}$ for $\mathrm{S}_{7.70} \mathrm{M}$ PC21 at $275 \mathrm{C}$.

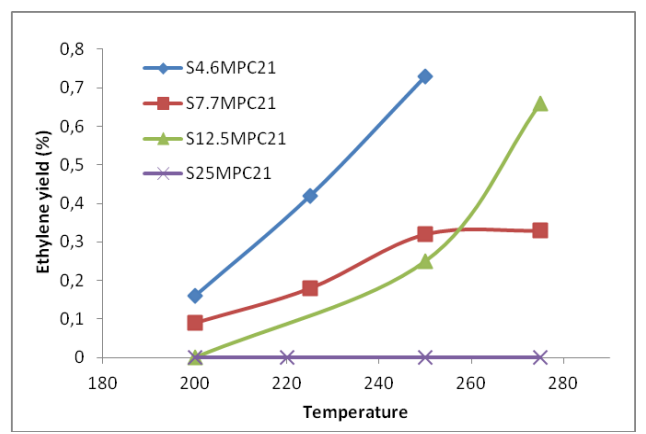

Fig. 10. Ethylene Yield as a function on reaction temperature for ethane oxidation over different supported $\mathrm{Mo}_{16} \mathrm{~V}_{6.37} \mathrm{Nb}_{2.05} \mathrm{Pd}_{1.844} \mathrm{O}_{\mathrm{x}}$ catalysts ( $\mathrm{P}=200$ psi, F/W: $15 \mathrm{ml} / \mathrm{min} . \mathrm{g}$. Cat.)

In spite of the high activity of $\mathrm{S}_{12.5} \mathrm{M} \mathrm{PC} 21$, it tended to produce undesirable products at expense of ethylene and acetic acid. The highest selectivity and then yield of carbon oxides were got for this catalyst. For example, at $240 \mathrm{C}$ where oxygen conversion was $99 \%$ Cox selectivity was $64 \%$ and their yield was $3.44 \times 10^{\wedge}-2$.Cox selectivities increased while 
ethylene and acetic acid decreased indicating that unselective structure formed by interaction between $\mathrm{Mo}_{16} \mathrm{~V}_{6.37} \mathrm{Nb}_{2.05} \mathrm{O}_{\mathrm{x}} \mathrm{Pd}$ and $\mathrm{S} 12.5$ surfaces catalyzed oxidation of ethylene and acetic acid to $\mathrm{CO}$ and $\mathrm{COx}$.

Therefore, these catalysts can be arranged based on their activities and selectivities of desirable products to become $\mathrm{S}_{25} \mathrm{M}$ PC21 is the best one and the second is $\mathrm{S}_{7.7} \mathrm{M}$ PC21 and then $\mathrm{S}_{12.5} \mathrm{M}$ PC21 and finally $\mathrm{S}_{4.6} \mathrm{M}$ PC21.

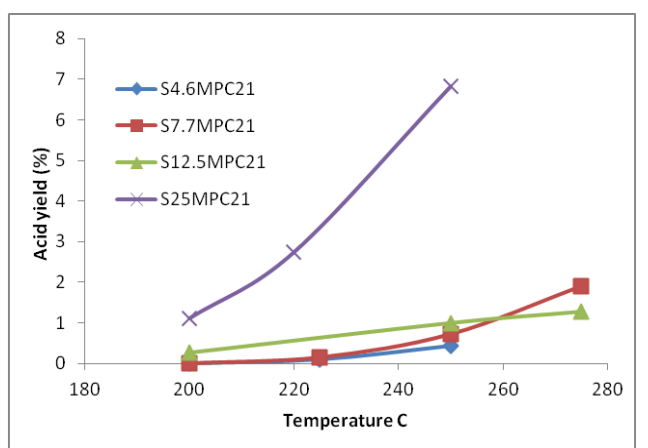

Fig.11. Acetic Acid Yield as a function on reaction temperature for ethane oxidation over different supported $\mathrm{Mo}_{16} \mathrm{~V}_{6.37} \mathrm{Nb}_{2.05} \mathrm{Pd}_{1.844} \mathrm{O}_{\mathrm{x}}$ catalysts ( $\mathrm{P}=200$ psi, F/W: 15 ml/min.g. Cat.)

\section{2) Optimum loading of nano-PdOX}

After $\mathrm{TiO}_{2}$ P25 was selected as the best support for $\mathrm{Mo}_{16} \mathrm{~V}_{6.37} \mathrm{Nb}_{2.05} \mathrm{Ox}$ catalyst in partial oxidation of ethane and how activity and acetic acid selectivity was enhanced in presence of palladium, it is important to discuss the effect of palladium loading to find out the optimum loading of nano-palladium.

Supported Mo-V-Nb over P25 was promoted with different amounts of nano- $\mathrm{PdO}_{\mathrm{X}}$. Ten different catalysts were prepared using different nano-palladium oxides loading shown in Table IV. Ethane oxidation over these catalysts was carried out at three reaction temperature $220 \mathrm{C}, 230 \mathrm{C}$, and $240 \mathrm{C}$ and total pressure $200 \mathrm{psi}$ with $15 \mathrm{ml} / \mathrm{min}$ feed flow rate. The results are shown in Table V-VII and Figs. 12-16.

It is seen that when nano- $\mathrm{PdO}_{\mathrm{X}}$ loading was above $0.05 \%$ all trends are almost the same with difference in catalytic activities. So we will focus on catalysts contain nano- $\mathrm{PdO}_{\mathrm{X}}$ loading below $0.05 \%$ and at $240 \mathrm{C}$ (only one reaction temperatures will be discussed due to different temperatures have almost shown the same trends).

Depending on the results, it is seen that the activity of catalysts were increased as nano-palladium oxides loading increase and it is clear in the range below $0.0125 \%$. Ethane and oxygen conversions were recorded the highest value at $0.0125 \%$ loading where their values were $8.49 \%$ and $84.47 \%$ respectively. The high activity of $\mathrm{Mo}_{16} \mathrm{~V}_{6.37} \mathrm{Nb}_{2.05} \mathrm{Pd}_{0.011} \mathrm{Ox} / \mathrm{TiO} 2\left(\mathrm{~S}_{25} \mathrm{MPC} 0.125\right)$ reflected on acetic acid selectivity where it was shown the heights selectivity and yield among the different loading. $\mathrm{S}_{25} \mathrm{M}$ PC $0.125 \%$ reordered $78.4 \%$ and $6.66 \times 10^{-2}$ acetic acid selectivity and yield respectively.

In contrast, ethylene recorded the top selectivity and yield at palladium loading $0.000625 \%$ which were $63.5 \%$ and $4.91 * 10^{-2} \%$ respectively. $\mathrm{S}_{25} \mathrm{M}$ PC $0.00625 \%$ also has shown the lowest selectivity and yield of carbon oxides which were $6.34 \%$ and $0.49 * 10^{-2} \%$. However we can conclude that $0.0125 \%$ is the optimum loading of nano-palladium oxides for oxidation of ethane to acetic acid over $\mathrm{Mo}_{16} \mathrm{~V}_{6.37} \mathrm{Nb}_{2.05} \mathrm{Ox}$ $/ \mathrm{TiO}_{2}(\mathrm{P} 25)$.

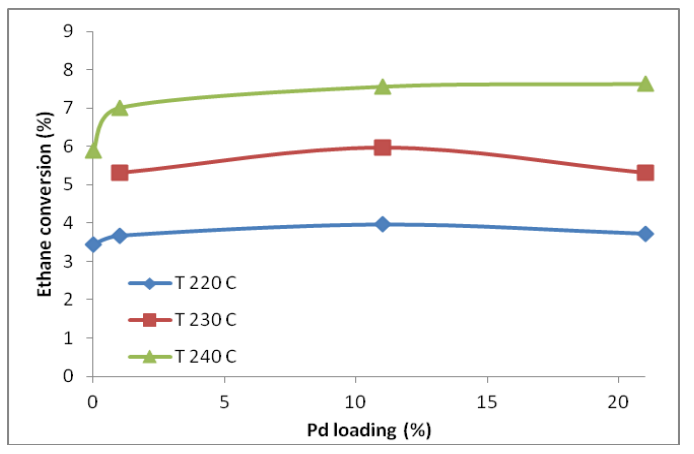

Fig. 12. Effect of nano-PdOx loading on Ethane conversion for $\mathrm{Mo}_{16} \mathrm{~V}_{6.37} \mathrm{Nb}_{2.05} \mathrm{PdIO}_{\mathrm{x}} / \mathrm{TiO}_{2}(\mathrm{P} 25)$ catalyst at various reaction temperatures, $200 \mathrm{psi}$ and $15 \mathrm{ml} / \mathrm{min}$

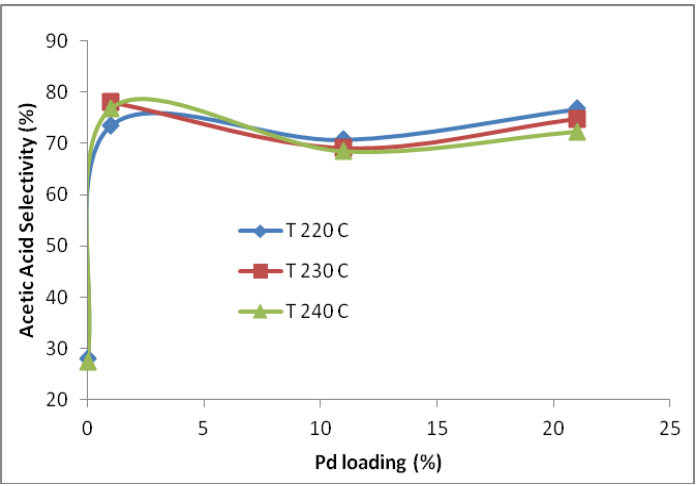

Fig. 13. Effect of nano-PdOx loading on Acetic Acid Selectivity for $\mathrm{Mo}_{16} \mathrm{~V}_{6.37} \mathrm{Nb}_{2.05} \mathrm{PdIO}_{\mathrm{x}} / \mathrm{TiO}_{2}(\mathrm{P} 25)$ catalyst at various reaction temperatures, $200 \mathrm{psi}$ and $15 \mathrm{ml} / \mathrm{min}$

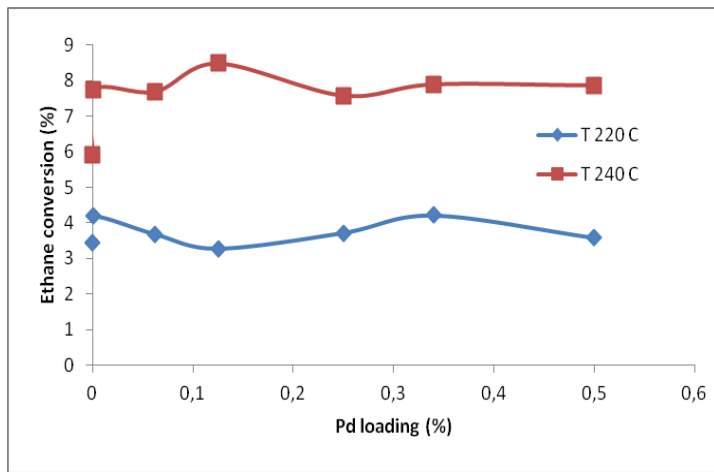

Fig.14. Effect of nano-PdOx loading on Ethane Conversion for $\mathrm{Mo}_{16} \mathrm{~V}_{6.37} \mathrm{Nb}_{2.05} \mathrm{PdIO}_{\mathrm{x}} / \mathrm{TiO}_{2}(\mathrm{P} 25)$ catalyst at $2200 \mathrm{C}$ and $240 \mathrm{C}$ reaction temperatures, $200 \mathrm{psi}$ and $15 \mathrm{ml} / \mathrm{min}$

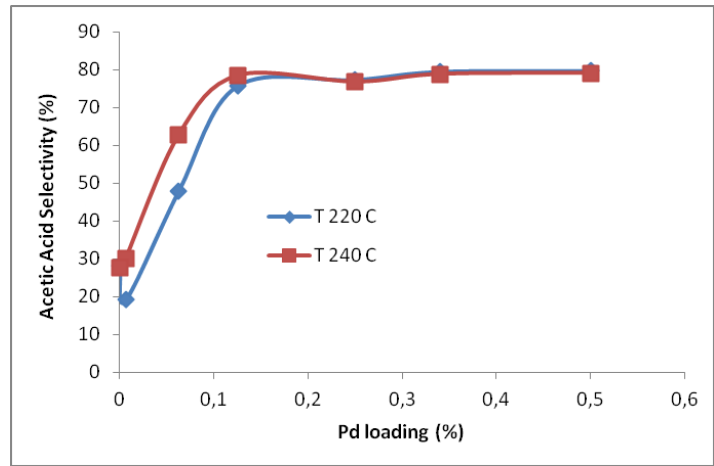

Fig. 15. Effect of nano-PdOx loading on Acetic Acid Selectivity for $\mathrm{Mo}_{16} \mathrm{~V}_{6.37} \mathrm{Nb}_{2.05} \mathrm{PdIO}_{\mathrm{x}} / \mathrm{TiO}_{2}(\mathrm{P} 25)$ catalyst at $2200 \mathrm{C}$ and $240 \mathrm{C}$ reaction temperatures, $200 \mathrm{psi}$ and $15 \mathrm{ml} / \mathrm{min}$. 
TABLE. V: SUMMARY OF EXPERIMENTAL RUNS OF $\mathrm{Mo}_{16} \mathrm{~V}_{6.37} \mathrm{Nb}_{2.05} \mathrm{PdIO}_{\mathrm{x}} / \mathrm{TiO}_{2}$ (P25) (S25MPCI) CATALYSTS WITH DIFFERENT LOADING OF PD (REACTION TEMPERATURE 220C; REACTION PRESSURE: 200 PSI FOR, F/W: 15 ML/MIN.G. CAT.)

\begin{tabular}{|c|c|c|c|c|c|c|c|c|c|}
\hline \multirow{2}{*}{$\begin{array}{l}\text { Cat. } \\
\text { Name }\end{array}$} & \multirow{2}{*}{$\begin{array}{c}\text { Pd } \\
\text { loading } \\
(\%)\end{array}$} & \multirow{2}{*}{$\begin{array}{c}\text { Oxygen } \\
\text { Con. (\%) }\end{array}$} & \multirow{2}{*}{$\begin{array}{c}\text { Ethane } \\
\text { Con. (\%) }\end{array}$} & \multicolumn{2}{|c|}{ Selectivity ( \% ) } & \multicolumn{2}{|c|}{ Yield $* 10^{-2}$} & \multicolumn{2}{|c|}{ Space time yield(gm/kgh) } \\
\hline & & & & Ethylene & Acetic Acid & Ethylene & Acetic Acid & Ethylene & Acetic Acid \\
\hline S25MPC21 & 2.1 & 46.8 & 3.72 & 0 & 73.54 & 0 & 2.74 & 0 & 180.5 \\
\hline S25MPC11 & 1.1 & 51.36 & 3.96 & 0 & 70.73 & 0 & 2.8 & 0 & 184.5 \\
\hline S25MPC1 & 0.1 & 44.61 & 3.67 & 0.06 & 76.74 & 0 & 2.82 & 0 & 185.8 \\
\hline $\mathrm{S} 25 \mathrm{MP} 0.5$ & 0.05 & 38.66 & 3.58 & 1.82 & 79.69 & 0.07 & 2.85 & 2.2 & 187.8 \\
\hline S25MP0.343 & 0.034 & 62.1 & 4.22 & 1.63 & 79.45 & 0.07 & 3.35 & 2.2 & 220.7 \\
\hline S25MP0.25 & 0.025 & 41 & 3.72 & 3.44 & 77.29 & 0.13 & 2.88 & 4 & 189.8 \\
\hline S25MPC0.125 & 0.0125 & 34.24 & 3.27 & 10.28 & 75.71 & 0.34 & 2.48 & 10.5 & 163.4 \\
\hline S25MPC0.0625 & 0.00625 & 30.49 & 3.68 & 42.54 & 47.78 & 1.57 & 1.76 & 48.3 & 116 \\
\hline S25MPC0.00625 & 0.000625 & 26.03 & 4.19 & 76.33 & 19.12 & 3.2 & 0.8 & 98.4 & 52.7 \\
\hline S25M & 0 & 20.16 & 3.44 & 66.53 & 28.13 & 2.29 & 0.97 & 70.4 & 63.9 \\
\hline
\end{tabular}

TABLE.VI. SUMMARY OF EXPERIMENTAL RUNS OF $\mathrm{Mo}_{16} \mathrm{~V}_{6.37} \mathrm{Nb}_{2.05} \mathrm{PdIO}_{\mathbf{x}} / \mathrm{TiO}_{2}(\mathrm{P} 25)$ (S25MPCI) CATALYSTS WITH DIFFERENT LOADING OF PALLADIUM (REACTION TEMPERATURE 230C; REACTION PRESSURE: 200 PSI FOR, F/W: 15 ML/MIN.G. CAT.)

\begin{tabular}{|c|c|c|c|c|c|c|c|c|c|}
\hline \multirow{2}{*}{$\begin{array}{l}\text { Cat. } \\
\text { Name }\end{array}$} & \multirow{2}{*}{$\begin{array}{l}\text { Pd loading } \\
(\%)\end{array}$} & \multirow{2}{*}{$\begin{array}{l}\text { Oxygen } \\
\text { Con. }(\%)\end{array}$} & \multirow{2}{*}{$\begin{array}{c}\text { Ethane } \\
\text { Con. (\%) }\end{array}$} & \multicolumn{2}{|c|}{ Selectivity ( \% ) } & \multicolumn{2}{|c|}{ Yield $* 10^{-2}$} & \multicolumn{2}{|c|}{$\begin{array}{c}\text { Space time } \\
\text { yield(gm/kgh) }\end{array}$} \\
\hline & & & & Ethylene & Acetic Acid & Ethylene & Acetic Acid & Ethylene & $\begin{array}{c}\text { Acetic } \\
\text { Acid } \\
\end{array}$ \\
\hline S25MPC21 & 2.1 & 55.86 & 4.6 & 0 & 74.83 & 0 & 3.442 & 0 & 226.7 \\
\hline S25MPC11 & 1.1 & 78.15 & 5.97 & 0 & 69.16 & 0 & 4.129 & 0 & 271.5 \\
\hline S25MPC1 & 0.1 & 59.59 & 5.3 & 0.08 & 78.07 & 0.004 & 4.138 & 0.1 & 272.1 \\
\hline $\mathrm{S} 25 \mathrm{M} 0.5$ & 0.05 & 55.69 & 5.26 & 1.29 & 79.91 & 0.068 & 4.203 & 2.1 & 276.7 \\
\hline S25M0.343 & 0.0343 & 85.24 & 5.64 & 1.07 & 79.48 & 0.06 & 4.483 & 1.8 & 295.2 \\
\hline $\mathrm{S} 25 \mathrm{M} 0.25$ & 0.025 & 53.79 & 4.62 & 2.82 & 76.05 & 0.13 & 3.514 & 4 & 231.3 \\
\hline S25MPC0.125 & 0.0125 & 61.43 & 6.06 & 5.3 & 76.95 & 0.324 & 4.663 & 10 & 307 \\
\hline S25MPC0.0625 & 0.00625 & 49.58 & 5.95 & 27.82 & 59.22 & 1.655 & 3.524 & 50.9 & 231.9 \\
\hline
\end{tabular}

TABLE. VII. SUMMARY OF EXPERIMENTAL RUNS OF SUPPORTED $\mathrm{Mo}_{16} \mathrm{~V}_{6.37} \mathrm{Nb}_{2.05} \mathrm{PdIO}_{\mathrm{x}} / \mathrm{TiO}_{2}(\mathrm{P} 25)$ (S25MPCI) CATALYSTS WITH DIFFERENT LOADING OF PALLADIUM (REACTION TEMPERATURE 240C ; REACTION PRESSURE: 200 PSI FOR, F/W: 15 ML/MIN.G. CAT.)

\begin{tabular}{|c|c|c|c|c|c|c|c|c|c|}
\hline Cat. & \multirow{2}{*}{$\begin{array}{c}\mathrm{Pd} \\
\text { loading } \\
(\%)\end{array}$} & \multirow{2}{*}{$\begin{array}{c}\text { Oxygen } \\
\text { Con. (\%) }\end{array}$} & \multirow{2}{*}{$\begin{array}{l}\text { Ethane } \\
\text { Con. }(\%)\end{array}$} & \multicolumn{2}{|c|}{ Selectivity ( \%) } & \multicolumn{2}{|c|}{ Yield $* 10^{-2}$} & \multicolumn{2}{|c|}{$\begin{array}{c}\text { Space time } \\
\text { yield }(\mathrm{gm} / \mathrm{kgh})\end{array}$} \\
\hline Name & & & & Ethylene & $\begin{array}{l}\text { Acetic } \\
\text { Acid }\end{array}$ & Ethylene & Acetic Acid & Ethylene & Acetic Acid \\
\hline S25MPC21 & 2.1 & 94.09 & 7.63 & 0 & 72.28 & 0 & 5.515 & 0 & 363.4 \\
\hline S25MPC11 & 1.1 & 99.1 & 7.56 & 0 & 68.42 & 0 & 5.173 & 0 & 340.8 \\
\hline S25MPC1 & 0.1 & 80.78 & 7.01 & 0.02 & 76.8 & 0.001 & 5.384 & 0.3 & 354.8 \\
\hline S25M0.5 & 0.05 & 84.08 & 7.87 & 0.88 & 79.1 & 0.069 & 6.225 & 2.1 & 410.2 \\
\hline S25M0.343 & 0.0343 & 84.2 & 7.9 & 1.2 & 78.8 & 0.095 & 6.225 & 2.9 & 410.2 \\
\hline $\mathrm{S} 25 \mathrm{M} 0.25$ & 0.025 & 83.92 & 7.58 & 1.7 & 76.76 & 0.129 & 5.818 & 3.9 & 383.3 \\
\hline S25MPC0.125 & 0.0125 & 84.47 & 8.49 & 3.6 & 78.4 & 0.306 & 6.656 & 9.4 & 438.6 \\
\hline S25MPC0.0625 & 0.00625 & 68.2 & 7.69 & 22.56 & 62.74 & 1.735 & 4.825 & 53.4 & 317.9 \\
\hline S25MPC0.00625 & 0.000625 & 49.69 & 7.73 & 63.51 & 30.15 & 4.909 & 2.331 & 151 & 153.6 \\
\hline S25M & 0 & 41.69 & 5.9 & 62.47 & 27.51 & 3.686 & 1.623 & 113.3 & 106.9 \\
\hline
\end{tabular}




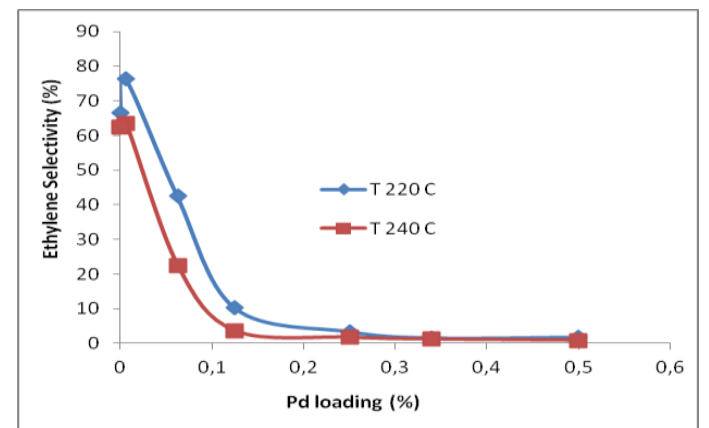

Fig. 16. Effect of nano-PdOx loading on Ethylene Selectivity for $\mathrm{Mo}_{16} \mathrm{~V}_{6.37} \mathrm{Nb}_{2.05} \mathrm{PdIO}_{\mathrm{x}} / \mathrm{TiO}_{2}(\mathrm{P} 25)$ catalyst at $220 \mathrm{C}$ and $240 \mathrm{C}$ reaction temperatures, $200 \mathrm{psi}$ and $15 \mathrm{ml} / \mathrm{min}$.

\section{CONCLUSION}

Partial oxidation of ethane to ethylene and acetic acid on multi-components oxides, $\mathrm{Mo}_{16} \mathrm{~V}_{6.37} \mathrm{Nb}_{2.05} \mathrm{O}_{\mathrm{x}}$, was enhanced by the structural dispersion of active oxides on Titania (Degussa, P25). Titania-containing catalysts merely reflect a higher dispersion of the active Mo- $\mathrm{V}-\mathrm{Nb}$ oxides species without detectable change in their intrinsic reactivity. However, negative effects were observed when supporting on the other titania grades cristal AF4.60, AF7.70, and AF12.5 because of the low surface area.

Ethane oxidation in the presence of nano-palladium oxides shifted the reaction toward acetic acid formation. The presence of nano- $\mathrm{PdO}_{\mathrm{x}}$ based co-catalyst did not influence ethane oxidation rates, but markedly increased acetic acid synthesis rates by merely converting ethylene intermediates to acetic acid.

Acetic acid recorded a high value of selectivity where ethylene was nearly depleted from the reactor effluent. The optimum loading of nano- $\mathrm{PdO}_{\mathrm{x}}$ was recorded at $0.0125 \%$.

\section{ACKNOWLEDGMENT}

The authors acknowledge the support provided by King AbdulAziz City for Science and Tecgnology for the support of this research under grant number AR-29-256.

\section{REFERENCES}

[1] E. M. Thorsteinson, Wilson, Journal of Catalysis, vol. 52, pp. 116, 1978.

[2] F. G. Young, E. M. Thorsteinson, U. S. Patent 4250 346, 1981.

[3] K. Karim, E. Mamedov, M. H. Al-Hazmi, A. H. Fakeeha, M. A. Soliman, Y. S. Al-Zeghayer, A. S. Al-Fatish, A. A. Al-Arify, U.S. Patent 6030 920, 2000.

[4] K. Karim, E. Mamedov, M. H. Al-Hazmi, A. H. Fakeeha, M. A. Soliman, Y. S. Al-Zeghayer, A. S. Al-Fatish, A. A. Al-Arify, U.S Patent 6310 241, 2001.

[5] K. Karim, E. Mamedov, M. H. Al-Hazmi, A. H. Fakeeha, M. A. Soliman, Y. S. Al-Zeghayer, A. S. Al-Fatish, A. A. Al-Arify, U. S. Patent 6383 977, 2002.

[6] H. Borchert, U. Dingerdissen, Ger.offen.de patent 19630 832, 1998.

[7] D. Linke, D. Wolf, U. Dingerdissen, S. Zeyb, M. Baerns, "Catalytic partial oxidation of ethane to acetic acid over Mo1 V0.25 Nb0.12 Pd0.0005 Ox Part I: Catalyst performance and reaction mechanism," Journal of Catalysis, vol. 205, pp. 16-31, 2002.

[8] D. Linke, D. Wolf, U. Dingerdissen, S. Zeyb, M. Baerns, "Catalytic Partial oxidation of ethane to acetic acid over Mo1 V0.25 Nb0.12 Pd0.0005 Ox Part II: Kinetic modeling," Journal of Catalysis vol. 205, pp. 32, 2002.

[9] X. Li, E.Iglesia, Applied Catalysis A: General. vol.334, pp. 339, 2008.

[10] X. Li, E. Iglesia, J. Phys. Chem. B, vol. 112, pp 15001, 2008.

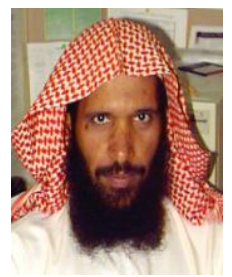

Yousef S. Al-Zeghayer is an associate professor at the Department of Chemical Engineering and Director of Industrial Catalysts Chair, King Saud University, Riyadh, Sudi Arabia. 